\title{
FAKTOR-FAKTOR YANG MEMPENGARUHI KINERJA PERUSAHAAN
}

\author{
Michael Hidayat \\ Program Studi Magister Manajemen Universitas Tarumanagara \\ michaelhidayat@ymail.com
}

\begin{abstract}
The Purpose Of This Research Is To Analyze Determinants Of Firm Performance In Non-Financial Companies Listed On Indonesia Stock Exchange. Determinants That Are Tested In This Research Include: Board Independence, Board Size, Firm Size, Firm Age, Liquidity, Leverage, Managerial Ownership, Female Board Members. The Object In This Research Is Non-Financial Companies Listed From 2011 Until 2014. The Population Of This Research Is 378 Non-Financial Companies. Sampling Techniques That Used In This Research Is Purposive Sampling. There Are 30 Non-Financial Companies Listed From 2011 To 2014 Which Met The Criterion Used As Sample. The Data Used Is Secondary Data That Collected From Financial Statement Of The Company. Analysis Method Of This Research Is Multiple Linier Regressions. The Result Of This Research Conclude That Board Independence, Leverage, And Female Board Members Have Influence Toward Firm Performance. Other Variable Such As Board Size, Managerial Ownership, Firm Size, Liquidity, And Age Firm Don’t Have Influence To Firm Performance.
\end{abstract}

Abstrak : Tujuan Dari Penelitian Ini Adalah Untuk Menganalisis Faktor-Faktor Penentu Kinerja Perusahaan Pada Perusahaan Non Finansial Yang Terdaftar Di Bursa Efek Indonesia. Faktor Penentu Yang Diuji Dalam Penelitian Ini Meliputi: Independensi Dewan, Ukuran Dewan, Ukuran Perusahaan, Usia Perusahaan, Likuiditas, Leverage, Kepemilikan Manajerial, Anggota Dewan Perempuan. Objek Dalam Penelitian Ini Adalah Perusahaan Non Finansial Yang Terdaftar Dari Tahun 2011 Hingga 2014. Populasi Penelitian Ini Adalah 378 Perusahaan Non Finansial. Teknik Pengambilan Sampel Yang Digunakan Dalam Penelitian Ini Adalah Purposive Sampling. Ada 30 Perusahaan Non-Keuangan Yang Terdaftar Dari 2011 Hingga 2014 Yang Memenuhi Kriteria Yang Digunakan Sebagai Sampel. Data Yang Digunakan Adalah Data Sekunder Yang Dikumpulkan Dari Laporan Keuangan Perusahaan. Metode Analisis Penelitian Ini Adalah Regresi Linier Berganda. Hasil Penelitian Ini Menyimpulkan Bahwa Independensi Dewan, Leverage, Dan Anggota Dewan Wanita Memiliki Pengaruh Terhadap Kinerja Perusahaan. Variabel Lain Seperti Ukuran Dewan, Kepemilikan Manajerial, Ukuran Perusahaan, Likuiditas, Dan Usia Perusahaan Tidak Memiliki Pengaruh Terhadap Kinerja Perusahaan.

Keywords: Firm Performance, Board Independence, Board Size, Managerial Ownership, Leverage, Firm Size, Female Board Members, Liquidity, and Age Firm

\section{PENDAHULUAN}

Banyak faktor yang dapat mempengaruhi Kinerja Perusahaan. Salah satu isu dalam penelitian kali ini adalah tentang menurunnya kinerja perusahaan PT HM SAMPOERNA Tbk. Perusahaan SAMPOERNA terpaksa untuk memecat 4.900 pegawainya mulai tanggal 31 Mei 2014. Hal ini terjadi karena adanya perubahan prefensi perokok dari SKT ke produk sigaret mesin terkanan lain juga muncul dari berbagai regulasi dalam negeri seperti cukai, pajak daerah, dan Peraturan Pemerintah Nomor 109 Tahun 2012 tentang Pengamanan Bahan yang Mengandung Zat Adiktif berita ini dilangsir dari Merdeka.com. Kinerja perusahaan 
dapat kita ukur dengan dengan menghitung berapa besarnya pendapatan bersih perusahaan. Mengetahui pendapatan perusahaan maka kita dapat memperkirakan berapa banyak aset yang dimiliki oleh perusahaan digunakan menjalankan kegiatan operasi perusahaan untuk menghasilkan pendatan bersih. Pada dasarnya perusahaan itu dapat berkembang apabila memiliki Direksi yang baik dalam mengolah perusahaan ataupun CEO yang mengerti akan keadaan perusahaannya saat ini. Serta juga dapat mengatur dalam penggunaan hutang untuk kegiatan perusahaan.

Tujuan dilakukan penelitian kali ini adalah untuk menemukan variabel-variabel yang mempengaruhi kinerja perusahaan karena hasil dari penelitian sebelumnya memberikan hasil yang tidak konsisten. Penelitian kali ini menggunakan variabel independen yaitu dewan independen, ukuran dewan direksi, kepemilikan dewan manajerial, leverage, ukuran perusahaan, dewan direksi wanita, likuiditas, usia perusahaandengan variabel dependen adalah kinerja perusahaan. Penelitian ini juga menggunakan dua grand theory yaitu agency theory dan stewardship theory.

\section{KERANGKA TEORITIS DAN PENGEMBANGAN HIPOTESIS Agency Theory}

Agency theory menguraikan hubungan antara pihak prinsipal dan agen, dimana prinsipal adalah pihak yang memberikan mandat kepada pihak agen. Prinsipal mendelegasikan tanggung jawab pengambilan keputusan kepada agen dimana hak dan kewajiban kedua belah pihak diuraikan dalam suatu perjanjian kerja yang saling menguntungkan.

\section{Stewardship Theory}

Stewardship theory menurut Daft (2013) adalah teori yang menggambarkan situasi dimana para manajer tidaklah termotivasi oleh tujuan-tujuan individu tetapi lebih ditujukan pada sasaran hasil utama mereka untuk kepentingan organisasi, dan melakukannya tanpa memiliki niat untuk mengontrol orang lain dengan tujuan tertentu.

\section{Dewan Independen dan Kinerja Perusahaan}

Penelitian yang dilakukan oleh Abor dan Biekpe (2007) dalam Vo dan Nguyen (2014) menunjukan bahwa terdapat hubungan yang sangat kuat dan positif antara komisaris non eksekutif dengan kinerja perusahaan.

\section{Ukuran Dewan Direksi dan Kinerja Perusahaan}

Penelitian yang dilakukan sebelumnya oleh Klein (1998) dalam Vo dan Phan (2013) menemukan bahwa ada pengaruh dari ukuran dewan direksi terhadap kinerja perusahaan.

\section{Ukuran Perusahaan dan Kinerja Perusahaan}

Menurut Jaussaud Kurashina (2008) dalam Gaur dan Gupha (2011) menyatakan terdapat pengaruh antara ukuran perusahaan dengan kinerja perushaan.

\section{Usia Perusahaandan Kinerja Perusahaan}

Menurut penelitian dari Jovanovic (1982) dalam Twairesh (2014) menjelaskan bahwa terdapat hubungan antara usia perusahaan dengan kinerja perusahaan. Usia perusahaan yang lama dapat menunjukan bagaimana kinerja perusahaan selama ini dalam mengatur dan mengelola perusahaan tersebut.

\section{Likuiditas dan Kinerja Perusahaan}

Menurut Jensen (1986) dalam Sari dan Usman (2014) menyatakan bahwa likuiditas mencerminkan hubungan positif dari nilai perusahaan. Dimana semakin besar nilai rasio yang dihasilkan maka semakin besar kemampuan perusahaan dalam melunasi hutang-hutangnya.

\section{Leverage dan Kinerja Perusahaan}

Menurut Chinaemerem and Anthony (2012) dalam Twairesh (2014) menemukan bahwa Leverage tidak berpengaruh terhadap kineja perusahaan.

\section{Kepemilikan Manajerial dan Kinerja Perusahaan}


Menurut Jensen dan Meckling (1976) dalam Sari dan Usman (2014) berpendapat bahwa terdapat hubungan positif dalam peningkatan kepemilikan manajerial antara pemegang saham dan manajer.

\section{Dewan Direksi Wanita dan Kinerja Perusahaan}

Menurut Adams dan Ferreira (2003) dalam Sari dan Usman (2014) juga menyatakan bahwa terdapat hubungan positif antara perwakilan direktur wanita dan kinerja perusahaan,

\section{HIPOTESIS}

Berdasarkan literatur di atas, penelitian ini ingin mengajukan beberapa hipotesis sebagai berikut:

$\mathrm{Ha}_{1}$ Dewan Independen berpengaruh positif terhadap kinerja perusahaan.

$\mathrm{Ha}_{2} \quad$ Ukuran dewan direksi berpengaruh positif terhadap kinerja perusahaan.

$\mathrm{Ha}_{3} \quad$ Ukuran perusahaan berpengaruh positif terhadap kinerja perusahaan.

$\mathrm{Ha}_{4} \quad$ Usia perusahaan berpengaruh positif terhadap kinerja perusahaan.

$\mathrm{Ha}_{5} \quad$ Likuiditas berpengaruh positif terhadap kinerja perusahaan.

$\mathrm{Ha}_{6}$ Leverage berpengaruh positif terhadap kinerja perusahaan.

$\mathrm{Ha}_{7} \quad$ Kepemilikan manajerial berpengaruh positif terhadap kinerja perusahaan.

Has Dewan direksi wanita berpengaruh positif terhadap kinerja perusahaan.

\section{KERANGKA PENELITIAN}

\begin{tabular}{|c|c|c|}
\hline Dewan Independen & Ukuran Dewan Direksi \\
\hline $\begin{array}{c}\text { Kepemilikan } \\
\text { Manajerial }\end{array}$ & $\begin{array}{c}\text { Lewan Perusahaan } \\
\text { Wineranita }\end{array}$ \\
\hline
\end{tabular}

\section{METODE PENELITIAN}

Teknik analisa data yang digunakan pada penelitian ini adalah teknik analisa regresi berganda yang dilakukan dengan bantuan program pengolahan statistik Statistical Product and Services Solutions (SPSS). Persamaan regresi berganda yang diintepretasikan dalam penelitian ini adalah:

$R O A=\beta_{0}+\beta_{1} D I+\beta_{2} U D+\beta_{3} U K R N P+\beta_{4} U S P+\beta_{5} L K D T S+\beta_{6} L V E+$ $\beta_{7} K M P M J+\beta_{8} D D W+e$

\section{$\beta_{0} \quad$ Konstanta}

DI Dewan Independen

UD Ukuran Dewan Direksi

UKRNP Ukuran Perusahaan

USP Usia Perusahaan

$\begin{array}{ll}\text { LKDTS } & \text { Likuiditas } \\ \text { LVE } & \text { Leverage } \\ \text { KMPMJ } & \text { Kepemilikan Manajerial } \\ \text { DDW } & \text { Dewan Direksi Wanita } \\ e & \text { error }\end{array}$

\section{DEFINISI OPERASIONAL DAN PENGUKURAN VARIABEL}

Variabel kinerja perusahaan dihitung berdasarkan perbandingan antara net income dengan total asset. Menurut Bhagat dan Black (2000) dalam Vo dan Nguyen (2014).

Variabel ukuran dewan direksi dapat diukur dari berapa banyak anggota direksi yang terpilih dari dalam perusahaan dan luar perusahaan menurut Klein (1998) dalam Duc Hong Fo dan Tri Minh Nguyen (2014). 
Variabel ukuran perusahaan diukur dengan logarithm natural dari total aset. Menurut Lim (2012) dalam Carvalho et al. (2013).

Variabel usia perusahaan diukur dengan cara menghitung lama perusahaan berdiri sampai tahun penelitian dilakukan. Menurut Harianto dan Sudomo (1998) dalam Kamaliah et al (2014).

Variabel likuiditas dapat diukur dengan uji rasio antara asset lancer dan hutang jangka pendek.Menurut Weston dan Copeland (1995) dalam Prihartanty (2011).

Variabel Leverage adalah rasio dari kewajiban jangka panjang perusahaan yang dimiliki agar perusahaan dapat berjalan atau melakukan kegiatan operasi. Menurut Hillier at al. (2010) dalam Twairesh (2014).

Variabel kepemilikan manajerial diukur dengan menggunakan rasio antara jumlah saham yang dimiliki manajer, direksi,dan dewan komisaris terhadap total saham yang beredar menurut Rustendi dan Jimmi (2008) dalam Wiranata dan Nugrahanti (2013).

Variabel dewan dreksi wanita dalam penelitian ini diukur dengann rumus yaitu jumlah dewan direktur wanita menurut Carter et al. (2003) dalam Sari dan Usman (2014).

\section{PEMILIHAN SAMPEL DAN PENGUMPULAN DATA}

Populasi dari penelitian ini adalah seluruh perusahaan non-keuangan yang terdaftar di Bursa Efek Indonesia dan periode penelitiannya adalah 2011-2014. Data yang diperoleh adalah data sekunder. Sampel yang digunakan sebanyak 30 perusahaan non-keuangan yang dipilih dengan menggunakan metode purposive sampling,

\section{HASIL DAN KESIMPULAN PENELITIAN}

Hasil pengujian dalam penelitian ini adalah sebagai berikut:

Tabel I Hasil Pengujian

\begin{tabular}{lrr}
\hline Variabel & $\begin{array}{c}\text { Unstandardized } \\
\text { Coefficients }\end{array}$ & Significance \\
\hline Konstanta & 0,12 & 0,899 \\
Dewan Independen & 0,002 & 0,015 \\
Ukuran Dewan Direksi & $-0,05$ & 0,141 \\
Ukuran Perusahaan & 0,04 & 0,233 \\
Usia Perusahaan & 0,00 & 0,477 \\
Likuiditas & $-0,004$ & 0,512 \\
Leverage & $-0,032$ & 0,003 \\
Kepemilikan Managerial & $-0,001$ & 0,065 \\
Dewan Direksi Wanita & 0,014 & 0,036 \\
\hline
\end{tabular}

Adjusted $\mathrm{R}^{2} 0,202 \quad$ F sig 0,000

Dari hasil uji t menunjukan bahwa nilai Sig dari dewan independen adalah 0,015 dan lebih kecil dari pada 0,05 maka $\mathrm{Ha}_{1}$ diterima yang artinnya dewan independen berpengaruh dengan kinerja perusahan. Dengan nilai koefisien sebesar 0,002 yang artinya dewan independen berpengaruh positif terhadap kinerja perusahaan. Hal ini dapat disebabkan karena setiap anggota dewan independen perusahaan memiliki kemampuan di bidang masing-masing dan efisien.

Dari hasil uji t di atas menunjukan bahwa nilai Sig dari ukuran dewan direksi adalah 0,141 dan lebih besar dari pada 0,05 maka $\mathrm{Ha}_{2}$ tidak diterima yang artinya dewan perusahaan tidak berhubungan dengan kinerja perusahan.

Dari hasil uji t di atas menunjukan bahwa nilai Sig dari ukuran perusahaan adalah 0,233 dan lebih besar dari pada 0,05 maka $\mathrm{Ha}_{3}$ tidak diterima yang artinya ukuran perusahaan tidak berhubungan dengan kinerja perusahan. 
Dari hasil uji t di atas menunjukan bahwa nilai Sig dari usia perusahaan adalah 0,477 dan lebih besar dari pada 0,05 maka Ha tidak diterima yang artinya usia perusahaan tidak berhubungan dengan kinerja perusahan.

Dari hasil uji t di atas menunjukan bahwa nilai Sig dari likuiditas adalah 0,512 dan lebih besar dari pada 0,05 maka $\mathrm{Ha}_{5}$ tidak diterima yang artinya likuiditas tidak berpengaruh dengan kinerja perusahan.

Dari hasil uji t di atas menunjukan bahwa nilai Sig dari leverage adalah 0,003 dan lebih kecil dari pada 0,05 maka $\mathrm{Ha}_{6}$ diterima yang artinya leverageberhubungan dengan kinerja perusahan. Dengan nilai koefisien sebesar -0,032 yang artinya leverage berpengaruh negatif terhadap kinerja perusahaan. Dikarenakan kemungkinan terlalu besarnya hutang perusahaan.

Dari hasil uji t di atas menunjukan bahwa nilai Sig dari kepemilikan dewan manajerial adalah 0,065 dan lebih besar dari pada 0,05 maka $\mathrm{Ha}_{7}$ tidak diterima yang artinya kepemilikan dewan manajerial tidak berhubungan dengan kinerja perusahan.

Dari hasil uji t di atas menunjukan bahwa nilai Sig dari dewan direksi wanita adalah 0,006 dan lebih kecil dari pada 0,05 maka $\mathrm{Ha}_{8}$ diterima yang artinya dewan direksi wanita berhubungan dengan kinerja perusahan. Dengan nilai koefisien sebesar 0,014 yang artinya dewan direksi wanita berpengaruh positif terhadap kinerja perusahaan. Hal ini dapat terjadi karena wanita memiliki kelebihan yang tidak dimiliki oleh anggota direksi laki-laki yaitu multi-tasking yang dapat membuat wanita bekerja melakukan dua atau lebih hal yang berbeda bersamaan sehingga meningkatkan kinerja perusahaan.

\section{PENUTUP}

Penelitian ini sudah selesai, penelitian ini dilakukan untuk mencari pengaruh antara dewan independen, ukuran dewan direksi, kepemilikan manajerial, leverage, ukuran perusahaan, dewan direksi wanita, likuidtas, usia perusahaan dengan kinerja perusahaan dalam perusahaan non-keuangan yang terdaftar di Bursa Efek Indonesia.

\section{REFERENSI:}

Carvalho, Pedro Guedes de, Zellia Derrasquerio Dan Pailo Macas Nunes. 2013. Profitability Determinants of Fitness SMEs: Empirical Evidence from Portugal Using Panel Data, Vol. 15, No. 34.

Daft, L.Richard. 2013. Leadership, $5^{\text {th }}$ Editions, South Weatern, Cengage Learning

Gaur, Jighyasu dan Ritu Gupta. 2011. Comparing firm performance on the basis of age, size, leverage, and group affiliation in Indian IT industry.

Jensen, Michael C. dan William H Meckling. 1976. Theory of the Firm: Managerial Behavior, Agency Costs and Ownership Structure, Journal of Financial Economics, October, 1976, Vol. 3, No. 4, pp. 305- 360.

Kamilah, Nasrizal Akbar dan Lexinta Kinanti. 2009. Analisis Pengaruh Rasio Aktivitas, Leverage Keuangan, Ukuran, dan Umur Perusahaan Terhap Profitabilitas Perusahaan Wholesale and Retail Trade yang Terdaftar di Bursa Efek Indonesia, Jurnal Ekonomi, Vol. 17, No. 3, 2009

Prihartanty, Rima. 2011. Analisis Pengaruh Rasio Likuiditas, Rasio Leverage, Rasio Aktivitas dan rasio profitabilitas terhadap net income growth (studi pada perusaaan perdagangan retail yang listed di BEI periode 2005-2009). Tesis. Magister Manajemen Universitas Diponegor. Semarang.

Sari, Derry Permata dan Bahtiar Usman. 2014. Pengaruh Board Structure dan Ownership Structure Terhadap Firm Performance pada Perusahaan Manufaktur yang Terdaftar di Bursa Efek Indonesia: e-Journal Manajemen Fakultas Ekonomi Universitas Trisakti, Vol. 1 No.2 
Twairesh, Abdullah Ewayed M. 2014.The Impact of Capital Structure on Firm's Performance Evidence from Saudi Arabia, journal of Applied Finance \& Banking, Vol. 4, No. 2, 2014, $183-193$.

Vo, Duc Hong dan Tri Minh Nguyen. 2014. The Impact of Corporate Governance on Firm Performance: Empirical Study in Vietnam, Vol. 6, No. 6.

Vo, Duc dan Thuy Phan. 2013. Corporate Governance and Firm Performance: Empirical Evidence from Vietnam.

Wiranata, Yulius Ardy dan Yeterina Widi Nugrahanti. 2013. Pengaruh Struktur Kepemilikan Terhadap Profitabilitas Perusahaan Manufaktur di Indonesia: Jurnal Akuntansi dan Keuangan, Vol. 15, No. 1 


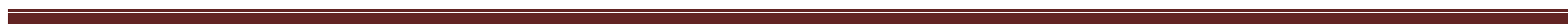
$\cdot$ 